\title{
On Climate in General and Floods in Particular Dams and Climate
}

\author{
Oleg Khalidullin* \\ L N Gumilyov Eurasian National University, Kazakhstan
}

Submission: April 08, 2019; Published: June 26, 2019

*Corresponding author: Oleg Khalidullin, Researcher, LN Gumilyov Eurasian National University, Kazakhstan

Keywords: Mankind; Diverse structure; Diversity; Atmospheric pressure; Temperature; Humidity

\section{Opinion}

Mankind always of its existence has been related to water and is consumer, considering it a resource for its comfort. Water is a living substance that has developed certain properties according to nature's assignments. Its main function is mediation in all earthly affairs. Passing through the soil and biota, it undergoes many transformations and goes into the atmosphere with the most diverse structure from each living creature and plant, breathing, various secretions, transpiration of plants.

Diversity, volumes, evaporation rate created a special mechanism that determines at each point of the planet strict constants of atmospheric pressure, temperature, humidity, on which all parameters of the atmospheric state depend: cyclones and anticyclones, movements and winds, charges of clouds and lightning discharges, places of precipitation, their volumes and schedule. It is these constants that have created strictly defined areas over millions of years - deserts and forests, tropics and savannas, and glaciers.

After precipitation, on the soil important water functions are the dissolution of mineral and organic substances in the banks of rivers and soils under the ground and their supply to plant roots and the stomachs of all living creatures. Water does not disappear in the roots of plants and the wombs of living beings. After numerous and diverse processes of growth of plants and organisms, the water continues its movement in a new substance. Vapors of evaporation and transpiration carry certain properties that control the growth and development of the entire biota. For example, smells provide the interaction of predators and prey, plant volatile production - nutrition and reproduction of plants. This cycle was created, developed and polished since the birth of life on Earth and, under the influence of solar heating, the geological structure of the planet is the main active element of nature - a kind of perpetual motion engine or source of all life on the planet.
One of the species of the animal world - MAN, subjugated nature to itself and its main mover - water. Man began to use the most common mineral on Earth, not only for drinking, but gradually turning it into working material. Taking it from nature, forced to perform new work functions. Read more at: [1]. Civilization began to collect it in huge man-made reservoirs, change its distribution by canals and irrigation, chained it into the aqueducts.

Ways of water conservation in rivers are based on the creation of bulky dams with the flooding of large areas and the creation of hydroelectric power plants (HPP). Man-made reservoirs are built on all continents, occupying more and more large areas with the destruction of biota.

The main problem of all the reservoirs is that the biota disappears under the reservoir mirror, and with it, the mechanism of water conversion in the animal and plant worlds, accumulated over millions of years. The area of plant leaves alone is 3 to 4 times the area of the entire land. Therefore, the magnitude of evaporation from land, not less evaporation from the entire area of the oceans - [2]. Untouched by 2015, this land remains 30\%. Everything else is taken from nature. Humanity at an accelerating pace destroys the last part of the land - these 30\%. More intensively builds hydroelectric power plants with the destruction of organic fumes.

According to the latest theory: [1] flooding of territories is the destruction of organic and increasing artificial evaporation, which leads the planet to an increase in natural disasters and global catastrophe.

Overflowing and devastating floods have become commonplace. The main cause of such flooding is shallowing of rivers. By nature, water continuously flushes soil particles off the banks and lays them on the bottom, dissolving the necessary substances. The bottom of the rivers is constantly growing and changing. To this was added the human factor - garbage, waste products, various items in the form of scrap - add a significant increase in raising the bottom. The garbage discharged into the 


\section{Ecology \& Conservation Science: Open Access}

rivers of settlements forms "thrombi" - underwater dams along the flow of water in the beds along the cities and downstream. This is where the most water comes out of the coast.

Rivers, with a decrease in depth, change their channels more intensively, expand floodplains and overflow. To eliminate flooding, it is necessary to maintain the depth, regularly remove sediment. But this is not the main thing, the main thing is that if we want to preserve the planet for our descendants, we must immediately begin to return to the water its natural functions.

One of the main elements of reducing artificial evaporation is the cessation of the construction of obsolete hydroelectric power plants with the flooding of areas and the release of all previously constructed reservoirs.

There is a brilliant invention of V.I. Bodyakina - [3], which ensures the preservation of the generation of electricity by the existing generators of these hydroelectric stations without dams. Head with the water moving in the pipes from the beginning of the reservoir with the rise to the top of the dam. It becomes possible to release all the reservoirs of the world without losing energy. All these areas will quickly become overgrown with necessary vegetation, and animal life will increase.

In order to preserve water according to human needs and to have minimal impact on water, it is necessary to fundamentally reconsider the possibilities of water accumulation in rivers. Considering the levels of rivers and their floodplains, we find a fairly large difference in the height of the water table in the river and the height of the banks of the floodplains. The narrow winding river at the bottom of the floodplain is the irrational use of the floodplain areas by nature itself. Meandering or gradual change of the riverbed is provided by nature to dissolve the mineral and organic substances of the intact soil of the banks in order to transfer them to the downstream animals and plants. The river "cares" about biota. The entire area, periodically eroded by spring water, is a drying out sandstone beach. Periodically, the channels reach untouched shores, erode, bring them down and the water absorbs useful substances. Millions of years of the river deepened and expanded, forming floodplains and canyons.

Is it possible to preserve the natural functions of water and create its safe accumulation? The accumulation of water for irrigation and water supply of cities can be created by small dams without raising above the banks of floodplains. The floodplains can be used as reservoirs for the accumulation of water in the spring and consumption in the summer. And ensure contact with the soil shores. Combine the interests of nature and human needs. To do this, it is enough to build a dam in the given places with a height not exceeding the height of the bank of the floodplain. And fill it almost to the brim with preservation of free capacity for flood waters. Many such dams form a cascade of lakes, providing the movement of fish and vessels. It turns out a full-flowing river, with a very large volume of water controlled by a chain of lakes distributed over the entire length of the river.
A significant difference from the cascades of large rivers such as the Volga and Yangtze are a high flow, which does not allow longterm storage of water, leading to its flowering and overgrowing.

Small dam heights - from 1-2 to 10-20 meters - do not pose a threat to coastal areas by floods. The filling of the floodplains is carried out within reasonable settlement limits, leaving stocks of free volume in each pool. They do not protrude above the surrounding squares; they fill only natural ones - barren floodplains and bare canyons. Naturally, in the body of such dams, culverts are constructed for taking water, spawning fish, moving ships and regulating levels in adjacent pools. Increased infiltration into underground streams will increase the volume of groundwater, which will give them even greater reserves and new sources away from the channels. It becomes possible to install small hydropower plants operating at a small height difference. There are no problems with dam structures with a height of 1-20 meters. No need for bulk concrete work, using ordinary earthmoving and road equipment. Sand-gravel, silt bottom mixture for the body of the dam is taken from the bottom of the same floodplain. To avoid overflowing floodplains with spring water and from heavy precipitation they are not filled. Concrete work is needed only for culverts and sluices.

There are places where there are no floodplains, and it is precisely in these places that the water overflows with floods. Floods in them come from the same reasons - silting and raising the bottom. All the rivers along the longitudinal profile of the bottom are saws, with the teeth upwards - the alternation of stretches depths and shallows - shoals. So, these natural stretches should be deepened to 10-30 meters, and rifts - shoals rise to the level of the coast, directing the flow through the culverts.

These works can be performed with existing dredging equipment. However, it is cumbersome, energy-intensive and requires high labor costs. There are several inventions that allow you to carry out any dredging work and solve the tasks with minimal cost. Use mainly the flow of the river itself. The essence of inventions is described in the articles: [4,5]. All these inventions are made in the form of proprietary technical solutions and require research and development.

Thus, it is possible to preserve water of the same volumes as in reservoirs with bulky dams, but without the risks of manmade disasters, reduced pressure on nature and increased natural functions of water. In foothill and mountain rivers, a chain of lakes with adjustable pools can become an obstacle to mudflows, and the watery surface that covers the narrow, blurred, disfigured multimeter in height, canyons among fir trees will adorn the mountain landscape, water gets access to fertile soil and is enriched with its salts. The river becomes a distributed reservoir of water, which changes the mode of small and transfer. hachy rivers. They can be navigable, they can generate electricity, and according to the ideas of V.I. Bodyakin using pipes, it is possible to use generators of existing hydroelectric stations without dams. 
Where there is no hydroelectric station, it is possible to create a micro hydroelectric station, distributed along the entire length of the river. But the most important thing is that vast areas of water are released in front of giant hydroelectric power plants, and the soil restores its natural state and organic evaporation.

In addition, new, unprecedented properties are added - all the rivers and even small ones become fish hatcheries, with a small overflow, through which the fish can easily jump. There are many bridges in given places, the possibility of organizing beaches, recreation areas. Small rivers become navigable and will not dry out during dry periods. Operational management of culverts will eliminate the movement of ice in the spring, and, consequently, floods due to congestion and groundwater. In the mountain rivers, a new strategy of protection is being created. Eliminates the need for the construction of bulky dam-protected dams with explosions, such as Medeo in Alma-Ata in the 1970s.

Political tensions in the world are disappearing - all transboundary rivers will no longer be problematic in the distribution of water between states.

\section{References}

1. Khalidullin O H (2018) Water Circulation and Climate Change. JOJ Wildl Biodivers 1(1): 555551.

2. https://vuzlit.ru/984043/transpiratsiya\#597.

3. http://5-bal.ru/geografiya/77972/index.html.

4. Halidullin O (2018) New Hydro-Engineering. Acta Scientific Agriculture 2(7): 99-104.

5. Khalidullin OH (2017) Prevention of Floods. J Fisheries Livest Prod 5(3): 246

Your next submission with Juniper Publishers
will reach you the below assets
- Quality Editorial service
- Swift Peer Review
- Reprints availability
- E-prints Service
- Manuscript Podcast for convenient understanding
- Global attainment for your research
- Manuscript accessibility in different formats
( Pdf, E-pub, Full Text, Audio)
- Unceasing customer service
Track the below URL for one-step submission
https://juniperpublishers.com/online-submission.php

